\title{
Caries prevalence and socioeconomic factors in children with sickle cell anemia
}

\section{Ana Cláudia Alves e Luna(a) Maria José Rodrigues ${ }^{(b)}$ Valdenice Aparecida Menezes ${ }^{(b)}$ Kátia Maria Gonçalves Marques(c) Fabiano Almeida dos Santos ${ }^{(a)}$}

(a) School of Dentistry, University of Pernambuco, Camaragibe, PE, Brazil.

(b) Departament of Pediatric Dentistry, School of Dentistry, University of Pernambuco, Camaragibe, PE, Brazil.

(c) Department of Clinical and Preventive Dentistry, School of Dentistry, Federal University of Pernambuco, Recife, PE, Brazil.
Declaration of Interests: The authors certify that they have no commercial or associative interest that represents a conflict of interest in connection with the manuscript.

Corresponding author:

Ana Cláudia Alves e Luna

E-mail: claudialuna20@hotmail.com

Received for publication on Aug 25, 2011 Accepted for publication on Nov 16, 2011

\begin{abstract}
The aim of the present study was to investigate caries prevalence and socioeconomic factors in children with sickle cell anemia. This study was conducted in 160 children with sickle cell anemia aged 3 to 12 years attending the Center for Hematology in Recife, Brazil. Data collection included interviews with guardians concerning social factors and oral examinations to determine the caries prevalence. Statistical analyses were performed using the Kruskal-Wallis and Pearson's chi-square tests at a $5 \%$ significance level. The caries prevalence was $55.0 \%$. The $\mathrm{dmft}$ index was 2.12, and the DMFT index was 1.50. Income significantly influenced $\mathrm{dmft}$; the mean $\mathrm{dmft}$ was 4.57 in children whose family income was less than the Brazilian minimum wage (BMW), whereas in children with a family income three times the BMW or higher, the mean $\mathrm{dmft}$ was 2.27. No statistically positive association was found between the educational level of parents and guardians and the caries indices. A statistically significant association was found between dental caries prevalence and family income.
\end{abstract}

Descriptors: Anemia, Sickle Cell; Oral Health; Dental Caries; Child; Socioeconomic Factors.

\section{Introduction}

Sickle cell anemia is a genetic disorder characterized by a mutant type of hemoglobin, called hemoglobin $\mathrm{S}(\mathrm{HbS})$, that causes the sickling of red blood cells. ${ }^{1}$ Sickle cell anemia is the most common hereditary disease in Brazil and worldwide. ${ }^{2-5}$ In Brazil, it is estimated that more than two million people carry the gene for $\mathrm{HbS}$, and over 8,000 individuals have the severe form (SS). Approximately 700,000 new cases of sickle-cell disease occur annually. ${ }^{6}$ The disease is prevalent among African descendents. ${ }^{6,7}$

Sickle cell anemia, although treatable, is a chronic incurable disease involving medical, dental, genetic, and psychosocial factors. ${ }^{7,8}$ Dentists play an important role in preventing complications and improving the quality of life of patients with sickle cell disease ${ }^{9}$ because these patients are more susceptible to infections and periodontal disease. ${ }^{10}$ These patients are also at a higher risk of developing dental caries because of the high prevalence of dental opacities (changes in the formation and calcification of enamel and dentin), the frequent and continuous use of medication containing sucrose, and the high frequency of complications and hospitalization brought about by the absence of proper oral hygiene. ${ }^{11}$ 
In the last two decades, there has been a marked decline in caries in Brazil and worldwide. ${ }^{12-14}$ Among the reasons for this are the addition of fluoride to toothpaste ${ }^{15}$ changes in caries diagnoses, ${ }^{16}$ water fluoridation and improvements in socioeconomic conditions. ${ }^{12,14,15}$

The literature provides little information on various aspects of sickle cell disease. For example, few studies have examined the increased prevalence of caries in individuals with sickle cell disease. ${ }^{17-22}$

Given the peculiarities of sickle cell anemia and its sequelae in the oral cavity, this study examined caries and socioeconomic factors in children with this disease.

\section{Methodology}

This study was approved by the Ethics in Research Committee of the Center of Hematology of Pernambuco (HEMOPE) (number 036/2007).

The investigation was designed as a cross-sectional study. This sample consisted of 160 patients with a clinical and laboratory diagnosis of sickle cell anemia treated at the HEMOPE in Recife, Brazil.

The children were examined as they sought care at HEMOPE, and the inclusion criteria were subjects aged 3 to 12 years, which allowed intra-oral examinations, and consent of the parents or guardians to participate in the study. The exclusion criteria were other systemic diseases, psychiatric or neurological disorders, or other factors that precluded oral examinations.

For the examination, we used medical records containing the odontogram to determine the $\mathrm{dmft}$ (number of decayed primary teeth, teeth extracted, and teeth that were filled) and DMFT (number of decayed permanent teeth, missing teeth, and teeth that were filled) indices in accordance with the World Health Organization (WHO) criteria. ${ }^{23}$ During the clinical examination, the examiner wore personal protective equipment (PPE) that met biosecurity standards and used a dental mirror and probe with a $0.5-\mathrm{mm}$ ball tip and black-ring between 3.5 and $5.5 \mathrm{~mm}$ from the tip to determine the Community Periodontal Index (CPI).

The interexaminer calibration consisted of a theoretical stage with the presentation of images and the criteria of the DMFT and dmft indices. A second stage was devoted to clinical practice, resulting in a Kappa of 0.825 . Intraexaminer calibration consisted of reviewing one in every ten children, resulting in a Kappa of 0.85 .

Data on socioeconomic characteristics were collected through a previously validated form by the validation method of face with 20 parents or guardians, addressing questions about home address, gender, age, education level of parents or guardians and family income. Individuals interviewed in the validation were not included in the final sample. The Brazilian minimum wage (BMW) was considered in calculating family income, and subjects were classified into 3 groups: less than one BMW, one to two times the BMW and more than two times the BMW. Educational level was classified as follows: elementary, high school and college education.

Data analyses were performed to obtain the following percentage measures and statistics: mean, median, and standard deviation. Kruskal-Wallis tests were used for comparisons. Pearson's chisquare tests were used to evaluate associations between categorical variables and groups, including the odds ratio (OR) and confidence interval values for the measures. The margin of error used was $5.0 \%$, and the intervals were obtained with a reliability of $95.0 \%$.

Data were entered into an Excel 2003 (Microsoft Corporation, USA) spreadsheet, and SPSS (Statistical Package for Social Sciences) version 13 (SPSS Inc., Chicago, USA) was used for all statistical calculations.

\section{Results}

This study included 160 children $(42.5 \%$ boys and $57.5 \%$ girls). The response rate was $100 \%$ of all invited children; all subjects met the inclusion criteria.

The mean dmft results showed that $78.7 \%$ of teeth were decayed, and $16.9 \%$ had been filled. The mean DMFT results for permanent teeth showed that $56 \%$ of the teeth were decayed, and $32 \%$ had been filled (Table 1).

Over half $(56.3 \%)$ of the parents and guardians had not completed their elementary education, 
Table 1 - DMFT, dmft, and sound teeth.

\begin{tabular}{|c|c|c|c|c|c|c|}
\hline \multirow{2}{*}{ Variable } & \multicolumn{6}{|c|}{ Statistics } \\
\hline & Mean & Median & SD & Minimum & Maximum & Average (\%) \\
\hline \multicolumn{7}{|l|}{ Deciduous } \\
\hline - Decayed & 1.67 & 0.00 & 2.63 & 0 & 14 & 78.77 \\
\hline - Extracted & 0.09 & 0.00 & 0.38 & 0 & 3 & 4.25 \\
\hline - Filled & 0.36 & 0.00 & 1.00 & 0 & 7 & 16.98 \\
\hline $\mathrm{dmft}$ & 2.12 & 1.00 & 2.99 & 0 & 17 & \\
\hline Healthy deciduous & 12.68 & 12.00 & 6.47 & 0 & 20 & \\
\hline \multicolumn{7}{|l|}{ Permanent } \\
\hline - Decayed & 0.84 & 0.00 & 1.66 & 0 & 10 & 56.00 \\
\hline - Missing & 0.18 & 0.00 & 0.60 & 0 & 4 & 12.00 \\
\hline - Filled & 0.48 & 0.00 & 1.12 & 0 & 6 & 32.00 \\
\hline DMFT & 1.50 & 0.00 & 2.42 & 0 & 13 & \\
\hline Healthy permanent & 13.47 & 12.00 & 7.59 & 1 & 28 & \\
\hline
\end{tabular}

$18.1 \%$ had completed elementary school, and $18.1 \%$ had completed high school (Table 2). The income of the majority of families was one to two times the BMW, and only $15.0 \%$ earned a salary.

There were no significant relationships between parental education levels and any of the examined variables ( $p>0.05$, Table 3$)$.

An examination of the influence of income on the average dmft and DMFT values (Table 4) revealed that decayed permanent teeth were more prevalent among those who had a family income of one to two times the BMW. The averages were correspondingly higher among children whose family income was less than the BMW. Income influenced $\mathrm{dmft}$; the mean dmft was 4.57 in children whose family income was less than the BMW, whereas in children with a family income more than twice the BMW, the mean dmft was 2.27. However, the only significant differences between income categories occurred in the mean $\mathrm{dmft}(p<0.05)$.

As Table 5 shows, more than half $(55.0 \%)$ of the sample had teeth with untreated caries. The prevalence of caries increased with age; caries prevalence was $36.0 \%$ among children 3 to 5 years old and $72.3 \%$ among those 9 to 12 years old. Caries prevalence was $6.6 \%$ higher in boys than in girls $(58.8 \%$ versus $52.2 \%)$. Caries prevalence varied little between categories based on the education levels of parents and guardians. Caries prevalence was
Table 2 - Distribution of children examined according to the education level of their parents and guardians and family income.

\begin{tabular}{l|r|r}
\hline \multicolumn{1}{c|}{ Variable } & $n$ & $\%$ \\
\hline \multicolumn{1}{l|}{ Education of parents and guardians } \\
\hline - Illiterate & 5 & 3.1 \\
\hline - Literate (from means outside of school) & 3 & 1.9 \\
\hline - Elementary education incomplete & 90 & 56.3 \\
\hline - Elementary school complete & 29 & 18.1 \\
\hline - High school complete & 29 & 18.1 \\
\hline - College degree & 4 & 2.5 \\
\hline Family Income & & \\
\hline - < the Brazilian minimum wage & 24 & 15.0 \\
\hline - 1 to 2 times the Brazilian minimum wage & 123 & 76.9 \\
\hline - $>2$ times the Brazilian minimum wage & 12 & 7.5 \\
\hline - Unreported & 1 & 0.6 \\
\hline & 160 & 100.0 \\
\hline
\end{tabular}

higher $(62.5 \%)$ among children with family incomes below the Brazilian minimum wage compared with those who had incomes more than twice the BMW $(50.0 \%)$. The only variable significantly associated with caries occurrence was age $(p<0.05)$.

\section{Discussion}

Although sickle cell anemia is the most common hematologic disease in Brazil, ${ }^{4}$ few studies have ex- 
Table 3 - Mean and standard deviation of the dmft and DMFT averages according to the education of parents and guardians.

\begin{tabular}{|c|c|c|c|c|}
\hline \multirow{3}{*}{ Variable } & \multicolumn{3}{|c|}{ Education of the parents or guardians } & \multirow{3}{*}{ P value } \\
\hline & $\begin{array}{l}\text { Elementary } \\
\text { education } \\
\text { incomplete }\end{array}$ & $\begin{array}{c}\text { Elementary school } \\
\text { complete / High school } \\
\text { incomplete }\end{array}$ & $\begin{array}{l}\text { High school complete / } \\
\text { College degree }\end{array}$ & \\
\hline & Mean \pm SD & Mean \pm SD & Mean \pm SD & \\
\hline \multicolumn{5}{|l|}{ Deciduous } \\
\hline - Decayed & $1.44 \pm 2.21$ & $1.92 \pm 3.37$ & $2.11 \pm 3.01$ & $p^{(1)}=0.632$ \\
\hline - Extracted & $0.08 \pm 0.31$ & $0.13 \pm 0.61$ & $0.11 \pm 0.31$ & $p^{(1)}=0.660$ \\
\hline - Filled & $0.32 \pm 1.00$ & $0.13 \pm 0.45$ & $0.68 \pm 1.28$ & $p^{(1)}=0.056$ \\
\hline dmft & $1.83 \pm 2.45$ & $2.17 \pm 3.52$ & $2.89 \pm 3.77$ & $p^{(1)}=0.299$ \\
\hline \multicolumn{5}{|l|}{ Permanent } \\
\hline - Decayed & $0.97 \pm 1.64$ & $0.85 \pm 2.25$ & $0.35 \pm 0.81$ & $p^{(1)}=0.199$ \\
\hline - Missing & $0.24 \pm 0.69$ & $0.10 \pm 0.45$ & $0.05 \pm 0.22$ & $p^{(1)}=0.386$ \\
\hline - Filled & $0.47 \pm 1.13$ & $0.45 \pm 1.15$ & $0.55 \pm 1.15$ & $p^{(1)}=0.798$ \\
\hline DMFT & $1.68 \pm 2.52$ & $1.40 \pm 2.68$ & $0.95 \pm 1.67$ & $p^{(1)}=0.374$ \\
\hline
\end{tabular}

(1): Kruskal-Wallis test.

Table 4 - Mean and standard deviation for dmft and DMFT according to family income (Brazilian minimum wage).

\begin{tabular}{|c|c|c|c|c|}
\hline \multirow{3}{*}{ Variable } & \multicolumn{3}{|c|}{ Income (BMW) } & \multirow{3}{*}{$P$ value } \\
\hline & \multirow{2}{*}{$\begin{array}{c}<\mathrm{BMW} \\
\text { Mean } \pm \mathrm{SD}\end{array}$} & \multirow{2}{*}{$\begin{array}{l}1 \text { to } 2 \text { times the } \\
\text { BMW } \\
\text { Mean } \pm \text { SD }\end{array}$} & \multirow{2}{*}{$\begin{array}{c}>2 \text { times the BMW } \\
\text { Mean } \pm S D\end{array}$} & \\
\hline & & & & \\
\hline \multicolumn{5}{|l|}{ Deciduous } \\
\hline - Decayed & $3.81 \pm 4.61$ (A) & $1.18 \pm 1.67^{(\mathrm{B})}$ & $2.00 \pm 2.83^{(A B)}$ & $p^{(1)}=0.059$ \\
\hline - Extracted & $0.29 \pm 0.78(\mathrm{AB})$ & $0.06 \pm 0.24(\mathrm{~A})$ & $0.00 \pm 0.00$ & $p^{(1)}=0.176$ \\
\hline - Filled & $0.48 \pm 1.12$ & $0.34 \pm 1.02$ & $0.27 \pm 0.65$ & $p^{(1)}=0.702$ \\
\hline $\mathrm{dmft}$ & $4.57 \pm 5.04(\mathrm{~A})$ & $1.58 \pm 2.10^{(B)}$ & $2.27 \pm 2.69(\mathrm{AB})$ & $\mathrm{p}^{(1)}=0.008^{*}$ \\
\hline \multicolumn{5}{|l|}{ Permanent } \\
\hline - Decayed & $0.69 \pm 1.54$ & $0.97 \pm 1.76$ & $0.10 \pm 0.32$ & $p^{(1)}=0.486$ \\
\hline - missing & $0.25 \pm 0.68$ & $0.19 \pm 0.62$ & $0.00 \pm 0.00$ & $p^{(1)}=0.834$ \\
\hline - Filled & $0.88 \pm 1.54$ & $0.45 \pm 1.09$ & $0.20 \pm 0.42$ & $p^{(1)}=0.123$ \\
\hline DMFT & $1.81 \pm 3.39$ & $1.61 \pm 2.33$ & $0.30 \pm 0.67$ & $\mathrm{p}^{(1)}=0.831$ \\
\hline
\end{tabular}

$\left({ }^{*}\right)$ : Significant difference at 5.0\%. (1): Kruskal-Wallis test. Note: If the letters in parentheses are distinct, a significant difference can be observed through Kruskal-Wallis comparisons. amined the oral health of children with this disease. These studies have observed an association between sickle cell anemia and dental caries, especially in children. However, these studies use different methodologies and samples, making it difficult to compare their results with the current results.

The main limitation of this study was that we examined a specific population and small number of cases. Therefore, the results should be interpreted cautiously, following the principles of special and external validity. ${ }^{16}$ We were forced to adopt this sampling model because of the difficulty in locating the study population.

Socioeconomic factors have been shown to influence caries risk. ${ }^{24,25}$ Low income may be associated with education levels and the value placed on health, lifestyle, and access to health care information. As a result, income may be an indirect factor for determining the susceptibility to dental caries..$^{25,26}$ Laurence $^{21}$ found that poor Africans with sickle cell 
Table 5 - Assessment of caries prevalence according to age, sex, and family income.

\begin{tabular}{|c|c|c|c|c|c|c|c|c|}
\hline \multirow{3}{*}{ Variable } & \multicolumn{4}{|c|}{ Caries } & \multirow{2}{*}{\multicolumn{2}{|c|}{ Total }} & \multirow{3}{*}{$P$ value } & \multirow{3}{*}{ OR (Cl 95\%) } \\
\hline & \multicolumn{2}{|c|}{ Yes } & \multicolumn{2}{|c|}{ No } & & & & \\
\hline & $n$ & $\%$ & $n$ & $\%$ & $\mathrm{n}$ & $\%$ & & \\
\hline \multicolumn{9}{|l|}{ Age (years) } \\
\hline - 3 to 5 & 18 & 36.0 & 32 & 64.0 & 50 & 100.0 & \multirow{4}{*}{$p^{(1)<0}<001^{*}$} & 1.00 \\
\hline - 6 to 8 & 23 & 51.1 & 22 & 48.9 & 45 & 100.0 & & $1.86(0.82-4.23)$ \\
\hline - 9 to 12 & 47 & 72.3 & 18 & 27.7 & 65 & 100.0 & & $4.64(2.10-10.26)$ \\
\hline - Total & 88 & 55.0 & 72 & 45.0 & 160 & 100.0 & & \\
\hline \multicolumn{9}{|l|}{ Sex } \\
\hline - Boys & 40 & 58.8 & 28 & 41.2 & 68 & 100.0 & \multirow{3}{*}{$p^{(1)}=0.403$} & 1.31 (0.69 - 2.47) \\
\hline - Girls & 48 & 52.2 & 44 & 47.8 & 92 & 100.0 & & 1.00 \\
\hline - Total & 88 & 55.0 & 72 & 45.0 & 160 & 100.0 & & \\
\hline \multicolumn{9}{|l|}{ Family Income } \\
\hline - Elementary education incomplete & 53 & 54.1 & 45 & 45.9 & 98 & 100.0 & \multirow{4}{*}{$p^{(1)}=0.941$} & 1.00 \\
\hline $\begin{array}{l}\text { Elementary school complete/High } \\
\text { school incomplete }\end{array}$ & 16 & 55.2 & 13 & 44.8 & 29 & 100.0 & & $1.05(0.45-2.40)$ \\
\hline - High school complete/College degree & 19 & 57.6 & 14 & 42.4 & 33 & 100.0 & & $1.15(0.52-2.56)$ \\
\hline - Total & 88 & 55.0 & 72 & 45.0 & 160 & 100.0 & & \\
\hline \multicolumn{9}{|l|}{ Brazilian minimum wage (BMW) } \\
\hline - $<$ the BMW & 15 & 62.5 & 9 & 37.5 & 24 & 100.0 & \multirow{4}{*}{$p^{(1)}=0.687$} & $1.67(0.41-6.77)$ \\
\hline - 1 to 2 times the BMW & 66 & 53.7 & 57 & 46.3 & 123 & 100.0 & & $1.16(0.35-3.79)$ \\
\hline - $>2$ times the BMW & 6 & 50.0 & 6 & 50.0 & 12 & 100.0 & & 1.00 \\
\hline - Total & 87 & 54.7 & 72 & 45.3 & 159 & 100.0 & & \\
\hline
\end{tabular}

$\left({ }^{*}\right)$ : Association significant at 5.0\%. (1): Pearson's chi-square test.

anemia were at an increased risk of tooth decay. These results provide evidence that low-income individuals are more likely to have more decayed teeth compared with individuals without the disease. These results concur with our findings, in which the mean dmft was 4.57 and the mean DMFT 1.81 in children whose family incomes were less than the Brazilian minimum wage. In children from families with incomes more than twice the BMW, the mean $\mathrm{dmft}$ and DMFT were 2.27 and 0.30 , respectively.

Although education is the indicator most widely used to measure socioeconomic status in epidemiological studies, we did not find a significant positive association between the education level of the parents and guardians (Table 3) and the mean dmft or DMFT, unlike other research conducted in the same subject area..$^{27,28}$
In a pilot study, Laurence et al..$^{19}$ found that patients with sickle cell anemia were more susceptible to dental caries than patients without the disease; the mean DMFT indices were 12.0 and 9.9, respectively. The results of the present study suggest that patients with sickle cell anemia are more susceptible to dental caries, although none of these differences was statistically significant.

The mean DMFT and dmft in our study were lower $(\mathrm{DMFT}=1.50, \mathrm{dmft}=2.12)$ than those found by Laurence. ${ }^{19}$ However, this finding should be interpreted with caution, as the sample in the aforementioned pilot study included adults, limiting comparisons because of the wide age range involved ( 6 to 92 years). This older sample was likely associated with much higher caries rates.

The prevalence of untreated caries in our group 
was $55.0 \%$, which was higher than the $22.95 \%$ prevalence found in a study of children aged 6 to 96 months in Bahia, Brazil. ${ }^{17}$ In Nigeria, Okafor ${ }^{18}$ reported that the caries prevalence in individuals with sickle cell anemia was $35.13 \%$, but they did not describe how they measured decay or how the statistical comparisons were made.

One of the goals of WHO in relation to oral health for 2010 was to obtain DMFT scores $\leq 1.0$ at 12 years of age. ${ }^{29}$ In our subjects, only the children aged 3-5 and 6-8 years attained the average recommended by WHO for 2010 .

Although socioeconomic status is considered a risk factor for caries, ${ }^{24,25}$ there are other biological, dietary and behavioral variables that were not considered in this study. These factors should be investigated in future studies. An important aspect to consider is that the prolonged use of drugs treating chronic diseases that are sweetened for children can cause harmful dental health effects, influencing caries activity. ${ }^{4,30}$

It is noteworthy that $45.0 \%$ of the children in the

\section{References}

1. Brasil. Ministério da Saúde. Secretaria de Atenção à Saúde. Departamento de Atenção Especializada. Manual de condutas básicas na doença falciforme. Brasília: Ministério da Saúde; 2006 [cited 2011 Ago 18]. Available from: http://bvsms.saude. gov.br/bvs/publicacoes/manual_condutas_doenca_falciforme. pdf.

2. Ashley-koch A, Yang Q, Olney RS. Sickle hemoglobin (HbS) allele and sickle cell disease: A HuGE review. Am J Epidemiol. 2000 May;151(9):839-45.

3. American Academy of Pediatrics. Section on Hematology/ Oncology, Committee on Genetics. Health supervision for children with sickle cell disease. Pediatrics. 2002 Mar;109(3):52635 .

4. Brasil. Ministério da Saúde. Secretaria de Atenção à Saúde. Departamento de Atenção Especializada. Manual de saúde bucal na doença falciforme. Brasília: Ministério da Saúde; 2007 [cited 2011 Ago 18]. Available from: http://bvsms.saude.gov. br/bvs/publicacoes/manual_saude_bucal_doenca_falciforme. pdf.

5. Brasil. Ministério da Saúde. Secretaria de Atenção à Saúde. Departamento de Atenção Especializada. Manual da anemia falciforme para a população. Brasília: Ministério da Saúde; 2007 [cited 2011 Ago 19]. Available from: http://bvsms.saude. gov.br/bvs/publicacoes/07_0206_M.pdf. present study were free of caries. The implementation of health promotion strategies appropriate to children with sickle cell anemia is important to obtain significant reductions in dental caries. These strategies should result in children with good oral health, growth, and development, less morbidity and fewer episodes of pain, infections, and sickle cell crises. Oral health status can have a great impact on the overall health and life quality of people with sickle cell anemia. ${ }^{11}$

\section{Conclusions}

As expected, our results, which showed a significant association between the prevalence of dental caries and socioeconomic factors, were similar to those reported by previous authors. This study found a high caries prevalence. There was a statistically significant difference between the mean $\mathrm{dmft}$ and family income; however no significant differences were found between the education level of parents and guardians and caries prevalence.

6. Brasil. Agência Nacional de Vigilância Sanitária. Manual de diagnóstico e tratamento de doenças falciformes. Brasília: ANVISA; 2002 [cited 2011 Ago 19]. Available from: http:// bvsms.saude.gov.br/bvs/publicacoes/anvisa/diagnostico.pdf.

7. Ramalho AS, Magna LA, Paiva-e-Silva RB. [Government Directive MS \# 822/01: unique aspects of hemoglobinopathies for public health in Brazil]. Cad. Saude Publica. 2003 JulAug:19(4):1195-99. Portuguese.

8. Serjeant GR, de Ceulaer K, Maude GH. Stilboestrol and stuttering priapism in homozygous sickle-cell disease. Lancet. 1985 Dec;326(8467):1274-6.

9. Fonseca M, Queis HS, Casamassimo PS. Sickle cell anemia: a review for the pediatric dentist. Pediatr Dent. 2007 MarApr;29(2):159-69.

10. Taylor LB, Nowak AJ, Giller RH, Casamassimo PS. Sickle cell anemia: a review of dental concerns and a retrospective study of dental and bony changes. Spec Care Dentist. 1995 JanFeb;15(1):38-42.

11. Brasil. Ministério da Saúde. Secretaria de Atenção à Saúde. Departamento de Atenção Especializada. Manual de Educação em Saúde. Brasília: Ministério da Saúde; 2008 [cited 2011 Ago 19]. Available from: http://bvsms.saude.gov.br/ bvs/ publicacoes/manual_educacao_saude_volume1.pdf. 
12. Narvai PC, Frazão P, Roncalli AG, Antunes JLF. Dental caries in Brazil: decline, polarization, inequality and social exclusion. Rev Panam Salud Publica. 2006 Jun;19(6):385-93.

13. Petersen, PE. The World Oral Health Report 2003: continuous improvement of oral health in the 21st century--the approach of the WHO Global Oral Health Programme. Community Dent Oral Epidemiol. 2003;31(1 Suppl):3-23.

14. Barbosa APM, Kriger L, Moysés ST, Moysés SJ. [Prevalence of illness caries in children of five years old in the city of Curitiba - critical analysi]. Epidemiol Serv Saude. 2007;16(2):142-5. Portuguese.

15. Cury JA, Tenuta LMA, Ribeiro CCC, Paes Leme AF. The importance of fluoride dentifrices to the current dental caries prevalence in Brazil. Braz Dent J. 2004 Sep-Dec;15(3):167-74.

16. Marcenes W, Freysleben GR, Peres MA. Contribution of changing diagnostic criteria toward reduction of caries between 1971 and 1997 in children attending the same school in Florianópolis, Brazil. Community Dent Oral Epidemiol. 2001 Dec;29(6):449-55.

17. Soares FF, Rossi TRA, Brito MGS, Vianna MIP, Cangussu MCT. [Conditions of oral health and socio-demographic factors in children from 6 to 96 months with sickle cell disease of Bahia]. Rev Odontol UNESP. 2010 Mar-Apr;39(2):115-21. Portuguese.

18. Okafor LA, Nonnoo DC, Ojehanon PI, Aikhionbare O. Oral and dental complications of sickle cell disease in Nigerians. Angiology. 1986 Sep;37(9):672-5.

19. Laurence B, Reid BC, Katz RV. Sickle cell anemia and dental caries: a literature review and pilot study. Spec Care Dentist. 2002 Mar-Apr;22(2):70-4.

20. Laurence B, Woods D, George D, Onyekwere O, Katz R, Lanzkron S, et al. Self-perceived loss of control and untreated dental decay in African American adults with and without sickle cell disease. J Health Care Poor Underserved. 2006 Aug;17(3):641-51.

21. Laurence B, George D, Woods D, Shosanya A, Katz RV, Lanzkron S, et al. The association between sickle cell disease and dental caries in African Americans. Spec. Care Dentist. 2006 May-Jun;26(3):95-100.
22. Soares FF, Rossi TRA, Brito MGS, Vianna MIP, Cangussu MCT. [Oral health status and demographic characteristics of children aged 6 to 96 months with sickle cell disease in the state of Bahia]. Rev Odontol Unesp. 2010 Mar-Apr;39(2):115-21. Portuguese.

23. World Health Organization. Oral health surveys: basic methods. $4^{\text {th }}$ ed. Geneve: World Health Organization; 1997. 168 p.

24. Sheiham A, Steele JG, Marcenes W, Tsakos G, Finch S, Walls AW. Prevalence of impacts of dental and oral disorders and their effects on eating among older people; a national survey in Great Britain. Community Dent Oral Epidemiol. 2001 Jun;29(3):195-203.

25. Spolidorio DMP, Höfling JF, Moreira D, Rodrigues JA de O, Boriollo MFG, Rosa EAR. Dental caries status in deciduous and permanent dentition of Brazilian children aged 6-8 years with a socio-economic base. Braz J Oral Sci. 2003 JanMar;2(4):147-51.

26. Meneghim MC, Kozlowski FC, Pereira AC, Ambrosano GM, Meneghim ZMAP. [Socioeconomic classification and the discussion regarding the prevalence of caries and dental fluorosis]. Cien. Saude Colet. 2007 Apr;12(2):523-9. Portuguese.

27. Tuon ACLF, Lacerda, J.T, Traebert, J. [Prevalence of dental caries in school pupils of the rural zone of Jacinto Machado, SC, Brazil]. Pesqui Bras Odontopediatria Clin Integr. 2007 Sep-Dec;7(3):277-84. Portuguese.

28. Moura C, Cavalcanti AL, Bezerra PKM. [Prevalence of dental caries in schoolchildren 12 years of age, Campina Grande, Paraiba, Brazil: a socioeconomic approach]. Rev Odonto Cienc. 2008 Jul-Sep;23(3):256-62. Portuguese.

29. Gomes PR, Costa SC, Cypriano S, Sousa MLR. [Paulínia, São Paulo, Brazil: situation of dental caries with WHO goals for 2000 and 2010]. Cad Saude Publica. 2004 MayJun;20(3):866-70. Portuguese.

30. Menezes VA de, Cavalcanti G, Mora C, Garcia AFG, Leal RB. [Pediatric medicines and their relationship to dental caries]. Braz J Pharm Sci. 2010 Nov;46(1):157-64 